ISSN 1678-3921

Journal homepage: www.embrapa.br/pab

For manuscript submission and journal contents, access: www.scielo.br/pab

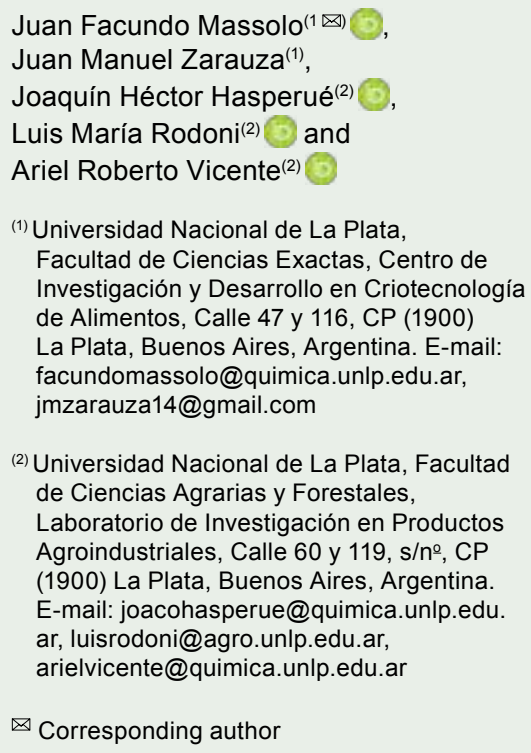

\section{Maturity at harvest and postharvest quality of summer squash}

\begin{abstract}
The objective of this work was to evaluate the influence of harvest at maturity on the composition, quality, and postharvest life of zapallito squash (Cucurbita maxima var. zapallito). Fruit were harvested at three developmental stages - small, medium, and large, with 30, 70, and $90 \pm 10-\mathrm{mm}$ diameter, respectively - and were stored at 0 and $5^{\circ} \mathrm{C}$ for 26 days and, then, at $20^{\circ} \mathrm{C}$ for 2 days. The following parameters were determined: respiration, firmness, color, chlorophyll content, carotenoids, sugars, acidity, phenolic compounds, antioxidants, decay, mass loss, and chilling injury (CI). Small light-colored squashes were more prone to dehydration and decay. Delaying harvest markedly reduced fruit carotenoid contents, acidity, and respiration rate; however, it did not affect firmness nor sugar content. Chlorophyll showed an increasing trend during fruit development. Small squashes had $100 \%$ higher levels of phenolic compounds and antioxidants than medium and large fruit, but were more sensitive to CI. No differences for CI susceptibility were observed between medium and large fruit. The quality of small, medium, and large squashes remained acceptable for 12,19 , and 26 days at $5^{\circ} \mathrm{C}$, respectively, plus 2 days at $20^{\circ} \mathrm{C}$.
\end{abstract}

Index terms: Cucurbita maxima, chilling injury, cucurbits, postharvest, storage.

\section{Maturidade à colheita e qualidade pós-colheita da abóbora de verão}

Resumo - O objetivo deste trabalho foi avaliar a influência da maturidade, à época da colheita, sobre a composição, a qualidade e a vida pós-colheita da abóbora "zapallito" (Cucurbita maxima var. zapallito). Os frutos foram colhidos em três estágios de desenvolvimento - pequeno, médio e grande, com diâmetros de 30,70 e $90 \pm 10 \mathrm{~mm}$, respectivamente - e foram armazenados a 0 e $5^{\circ} \mathrm{C}$ por 26 dias e, posteriormente, a $20^{\circ} \mathrm{C}$ por 2 dias. Determinaram-se os seguintes parâmetros: respiração, firmeza, cor, teor de clorofilas, carotenoides, açúcares, acidez, compostos fenólicos, antioxidantes, podridões, perda de massa e dano pelo frio (CI). As abóboras pequenas de cor clara foram mais propensas à desidratação e à podridão. $\mathrm{O}$ atraso da colheita reduziu acentuadamente o conteúdo de carotenoides, a acidez e a taxa de respiração da fruta; no entanto, não afetou a firmeza nem o teor de açúcar. Já a clorofila mostrou uma tendência crescente durante o desenvolvimento da fruta. As abóboras pequenas apresentaram níveis $100 \%$ maiores de fenólicos e antioxidantes do que as frutas médias e grandes, mas foram mais sensíveis ao CI. Não se observaram diferenças quanto à suscetibilidade ao CI entre as frutas médias e grandes. A qualidade das abóboras pequenas, médias e grandes permaneceu aceitável por 12,19 e 26 dias a $5^{\circ} \mathrm{C}$, respectivamente, mais 2 dias a $20^{\circ} \mathrm{C}$.

Termos para indexação: Cucurbita maxima, dano pelo frio, cucurbitáceas, pós-colheita, armazenamento. 


\section{Introduction}

The Cucurbitaceae family comprises several commercially important species, including climacteric edible fruits, such as melons and watermelons, and nonclimacteric fruits like cucumbers and the highly diverse squash group (Rajasree et al., 2016). Summer squashes are soft rind fruit, with a short production cycle (45-60 days from planting to harvest), commonly produced during the warm season, in subtropical regions (Suslow \& Cantwell, 2014). They include several types such as zucchini, yellow straightneck, crookneck, scallop, and zapallito squashes among others. For most fruit species, maturity at harvest and storage temperature are key determinants of the responses to the postharvest environment (Ahmad $\&$ Siddiqui, 2015). The influence of these factors has been extensively studied in most major cucurbit species, but data remain incomplete for several types of summer squashes.

Zapallito (Cucurbita maxima var. zapallito) summer squashes are characterized by a round to ellipsoidal shape, and a soft and green rind, which - in some cases - may have dark radial stripes. They are cultivated in subtropical and warm areas of South America, where their production may be comparable to that of major vegetables, such as tomato, and can be harvested in an immature stage. Similarly to other summer squashes, zapallito quality is based on shape and color uniformity, overall firmness, rind tenderness, and lack of mechanical damage and decay (Suslow \& Cantwell, 2014). As many immature fruit vegetables, zapallito has a wide harvest window. Fruit is normally picked when reaching a relatively large size, before rind hardens and excessive seed elongation occur (Massolo et al., 2014). Despite that, in many cases, they may be harvested earlier in response to market demands. Recently, there has been an increased interest in the production of "baby" vegetables (Kaiser \& Ernst, 2013), which may satisfy the demand of premium distribution channels able to pay an extra price for such specialties. Information on growth, quality, composition, and postharvest life of zapallito is very scarce and fragmentary. The few scientific reports available suggest that it may differ significantly from zucchini despite their systematic proximity (Contacto Rural..., 2012). Indeed, storage at $0^{\circ} \mathrm{C}$ caused no major chilling injury symptoms in zapallito after one week (Massolo et al., 2013), but induced watersoaked pitting, discoloration, and decay within 48 hours in zucchini (Molinar et al., 1999). Therefore, it is important to increase the understanding regarding the developmental changes and storage performance of this summer squash type.

The objective of this work was to evaluate the influence of harvest at maturity on the composition, quality, and postharvest life of zapallito squash.

\section{Materials and Methods}

Summer squashes were harvested in a greenhouse in La Plata, Argentina $\left(34^{\circ} 59^{\prime} \mathrm{S}, 58^{\circ} 3^{\prime} \mathrm{W}\right)$, from November to February 2017. Fruit were grown under natural light, in an arched shape $7.5 \mathrm{~m}$ wide and 21.0 $\mathrm{m}$ long greenhouse, with a transparent, $150 \mu \mathrm{m}$ thick, low-density polyethylene cover treated against the action of ultraviolet rays. Temperatures were adjusted between 25 and $32^{\circ} \mathrm{C}$ by ventilation laterals. Seedlings were planted in two staggered rows per bed with $0.50 \mathrm{~m}$ between plants in the row, and $0.70 \mathrm{~m}$ between rows. Air relative humidity ranged from $70-80 \%$. Irrigation was conducted every day. Water volume was theoretically calculated based on soil-water retention properties. Irrigation was carried out using a PVC tank (500 L), with the EBD250076 self-venting circulation electric pump (Metalcorte, Caxias do Sul, RS, Brazil), with $16 \mathrm{~mm}$ diameter lateral lines and microtube emitters, with $2.5 \mathrm{~L} \mathrm{~h}^{-1}$ mean flow rate. Fertilization was applied by drip irrigation throughout the growing cycle, and consisted of $80 \mathrm{~g}$ per plant of a $10 \mathrm{~N}, 2.2 \mathrm{P}_{2} \mathrm{O}_{5}$, $24.9 \mathrm{~K}_{2} \mathrm{O}$ plus micronutrient commercial fertilizer. Fruit set was achieved either by natural pollination. Fruit were harvested at three different developmental stages - small (25-35 mm diameter), medium (65-75 $\mathrm{mm}$ diameter), and large (85-95 $\mathrm{mm}$ diameter) - and then were transported to the laboratory (Figure $1 \mathrm{~A}$ ). Fruit were washed in chlorinated water $\left(100 \mathrm{mg} \mathrm{L}^{-1} \mathrm{pH}\right.$ 6.5) for $1 \mathrm{~min}$, packed in plastic trays in groups of five, and covered with a perforated PY8 film, with 15441.7 $\mathrm{mm}$ diameter perforations per square meter (Cryovac, Sealed Air: Food Care, Charlotte, NC, USA). Samples were stored at $5^{\circ} \mathrm{C}$, at $90 \%$ relative air humidity, for 0 , 12,19 , or 26 days. After removal from cold storage, the trays were held for 2 days at $20^{\circ} \mathrm{C}$ to simulate a shelf-life period. Three replicates with 30 fruit each were evaluated for each stage and storage time. At

Pesq. agropec. bras., Brasília, v.54, e00133, 2019

DOI: 10.1590/S1678-3921.pab2019.v54.00133 
different times, samples were taken and immediately analyzed, or otherwise frozen in liquid $\mathrm{N}_{2}$ and stored at $-80^{\circ} \mathrm{C}$ until use. For the assessment of susceptibility to chilling injury, fruit were washed and packed as previously described, stored at $0^{\circ} \mathrm{C}$ for 12 days, at $90 \%$ relative humidity, and, subsequently, stored at $20^{\circ} \mathrm{C}$ for 2 days.

For starch assessment, a saturated aqueous solution of iodine was prepared in IK $(10 \% \mathrm{w} / \mathrm{v})$. Drops of this solution were poured on squash halves. After $5 \mathrm{~min}$, the iodine solution was drained, and the excess was rinsed with distilled water. Zones showing a purple coloration indicated starch presence (Raffo et al., 2011).

Respiration rate was measured according to Cote et al. (2013). Fruit were placed in a 3-L airtight flask, and incubated for $10 \mathrm{~min}$ at $20^{\circ} \mathrm{C}$. The initial and final $\mathrm{CO}_{2}$ concentrations in the headspace were recorded with the Alnor CompuFlow 8650 infrared sensor (TSI, Shoreview, MN, USA); the results were expressed as mmol $\mathrm{CO}_{2} \mathrm{~kg}^{-1} \mathrm{~h}^{-1}$. To evaluate the stress reponse induced by exposure to chilling temperatures, the burst in respiration was also calculated in fruit stored at $0^{\circ} \mathrm{C}$ relatively to squashes held under nonchilling conditions, at $5^{\circ} \mathrm{C}$, after a 2-day shelf-life period at $20^{\circ} \mathrm{C}$. Measurements were done in triplicate.

Color space coordinates L*, $\mathrm{a}^{*}$, and $\mathrm{b}^{*}$, according to International Commission on Illumination (CIE), were obtained with the CR-400 Chroma Meter (Konica Minolta sensing Americas, Inc, Ramsey, NJ, USA).

Chlorophyll content (mg kg-1) was determined according to Villarreal et al. (2010), with slight modifications. Measurements were also done in triplicate.

Carotenoid content was calculated according to Cote et al. (2013) using an extinction coefficient of $1.39 \times 10^{5}$ $\mathrm{M}^{-1} \mathrm{~cm}^{-1}$ and expressed in $\mathrm{mg} \mathrm{kg}^{-1}(\mathrm{FW})$.

Fruit texture was determined, without peel removal, in the TA.XT2 texture analyzer (Stable Micro Systems Ltd, Surrey, UK) equipped with a 3-mm diameter probe. Each fruit was compressed $10 \mathrm{~mm}$ in the equatorial region at $1 \mathrm{~mm} \mathrm{~s}^{-1}$ speed rate. The initial slope of the compression curves (firmness, $\mathrm{N} \mathrm{s}^{-1}$ ) and probe displacement until tissue mechanical failure (DR, mm) were recorded.

Total sugars (grams of glucose per kilogram of FW) were measured according to Lemoine et al. (2010), with some changes. Acidity $\left(\mathrm{H}^{+}\right.$meq kg $\left.{ }^{-1} \mathrm{FW}\right)$ was determined according to Langer et al. (2018). Phenolic compounds (milligrams of chlorogenic acid per kilogram of FW) were obtained according to Hasperué et al. (2016), with slight modifications. Antioxidant capacity, i.e., trolox equivalent-antioxidant capacity (TEAC) in $\mathrm{mg} \mathrm{kg}^{-1} \mathrm{FW}$, against the radical $\mathrm{ABTS}^{+}$was measured as in Arnao et al. (2001).

For mass loss evaluation, fruit were individually weighed at the beginning of the experiment and during the storage period. Results were expressed in percentage.

Fruit deterioration was visually assessed using a four-step hedonic scale, as follows: 0, no defects; 1, incipient deterioration; 2, slight deterioration; 3 , moderate deterioration; 4, full deterioration. The deterioration index (DI) was then calculated by the equation DI $=\Sigma$ (deterioration level $\times$ number of fruit on each level) / total number of fruit. Fruit were considered marketable when $\mathrm{DI} \leq 2.5$.

Chilling injury was calculated as the percentage of fruit stored at $0^{\circ} \mathrm{C}$ that showed surface depressions, pitting, scalds, and increased susceptibility to decay, in comparison with fruit held at $5^{\circ} \mathrm{C}$. Chilling injury severity was determined by using the four-step hedonic scale indicated above. Thirty fruit were evaluated for each sampling date and maturity stage.

Measurements were done in triplicate for respiration rate, chlorophyll content, carotenoid content, sugars, acidity, phenolic compounds, and antioxidant capacity against $\mathrm{ABTS}^{+}$. For texture and color assessments, 30 measurements were done per developmental stage and storage time.

A factorial design was used with the factors fruit maturity stage and storage time. Data were subjected to the analysis of variance, and means were compared by Fisher's test, at $5 \%$ probability, using the SAS software (SAS Institute Inc., Cary, NC, USA).

\section{Results and Discussion}

Fruit showed residual starch in the placental region surrounding the seed at all three stages tested (Figure $1 \mathrm{~B})$. The respiration rate of ca. $1 \mathrm{mmol} \mathrm{kg}^{-1}$ per hour (RR) obtained for large squashes (Figure $1 \mathrm{C}$ ) was similar to that reported for other immaturely harvested fruits such as cucumber (Cucumis sativus L.) and eggplant (Solanum melongena L. ) (Cantwell \& Kasmire, 2002; Zaro et al., 2014). "Baby" zapallitos showed the highest RR, whereas no differences were 
recorded between medium and large fruit. Postharvest changes in RR depended on fruit maturity stage at harvest. Medium or large-sized squashes showed no significant changes $(\mathrm{p}>0.05)$ for $\mathrm{RR}$ during storage at $5^{\circ} \mathrm{C}$. In contrast, small fruit showed an increasing trend. This unexpected pattern, given the nonclimacteric nature of summer squash, may be caused by a lowtemperature stress response in young fruit, which may be more sensitive to chilling (Boonsiri et al., 2007). Besides the rise in respiration, no visual chilling injury symptoms were detected in small fruit throughout the storage period at $5^{\circ} \mathrm{C}$.

During development, fruit became darker, as evidenced by a decline of lightness between "baby" and large fruit prior to storage (Table 1). Fruit ranked as small and medium showed similar color hue values at harvest. In contrast, large squashes showed higher-hue angle values, indicating that the fruit turned greener during late development. This fact, together with the rapid growth observed in the late development period, shows an increase in the ability of fruit to synthesize chlorophyll during development, as opposed to what occurs in other species (Ignat et al., 2013). Small zapallitos showed a clear tendency to yellow in cold storage, as depicted by the rapid decrease in hue values. The reduction in the hue angle during cold storage was three-fold lower in medium and large squashes, compared with small fruit. Loss of green color occurred in large fruit only when the storage period was longer than 19 days. At harvest, the carotenoid content (Table 1) of small summer squash was $60 \%$ higher than that in medium and large fruit. Increased nutrient density has also been reported in other "baby" vegetables in relation to their mature counterparts (Zaro et al., 2014). The differences in carotenoid content between small, medium, and large zapallito fruit became greater during storage. This is consistent with the results found by Obrero et al. (2013) for zucchini (Cucurbita pepo L.). Chlorophyll a was one-fold higher than chlorophyll $b$ at all three stages (Table 1). In line with the changes described for surface color, chlorophylls tended to accumulate at highest levels in medium and large squashes by $30-50 \%$, after $12+2$ days at $5^{\circ} \mathrm{C}$, confirming that the biosynthetic ability of fruit persists even at temperatures as low as $5^{\circ} \mathrm{C}$. This behavior differs from most other species of the same family, in which the content of chlorophyll decreases throughout storage (Hurr et al., 2009). A net loss of both chlorophylls a and $\mathrm{b}$ occurred at longer storage times, as has been reported for other green commodities and when senescence processes start to take over (Costa et al., 2006).

At harvest, firmness and fruit distance to rupture (DR) were similar, regardless of maturity stage
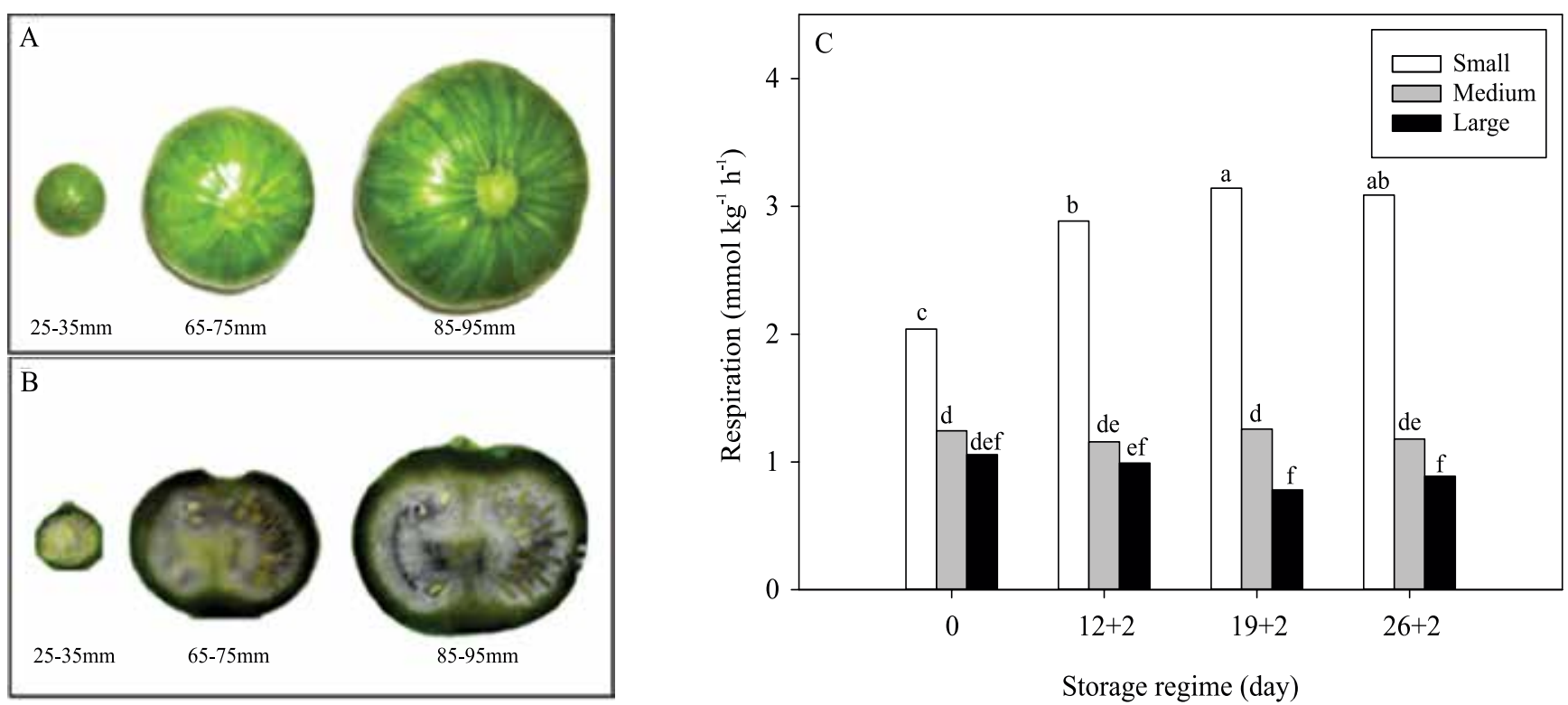

Figure 1. Appearance of small, medium, and large fruit (A), qualitative starch evaluation (B), and respiration rate (C) of zapallito summer squash (Cucurbita maxima) stored for $0,12,19$, or 26 days at $5^{\circ} \mathrm{C}$ and for 2 days at $20^{\circ} \mathrm{C}$. Different letters indicate significant differences by Fisher's test, at 5\% probability. 
Table 1. Lightness, chroma, hue angle, carotenoid content, chlorophyll a, and chlorophyll b of zapallito summer squash (Cucurbita maxima) stored for $0,12,19$, or 26 days at $5^{\circ} \mathrm{C}$ and for 2 days at $20^{\circ} \mathrm{C}^{(1)}$.

\begin{tabular}{|c|c|c|c|c|c|}
\hline \multirow[t]{2}{*}{ Parameter } & \multirow{2}{*}{$\begin{array}{l}\text { Developmen- } \\
\text { tal stage }\end{array}$} & \multicolumn{4}{|c|}{ Storage regime $(\text { days })^{(2)}$} \\
\hline & & 0 & $12+2$ & $19+2$ & $26+2$ \\
\hline \multirow{3}{*}{ Lightness } & Small & $54.4 \mathrm{ab}$ & $55.1 \mathrm{a}$ & $55.8 \mathrm{a}$ & $55.0 \mathrm{a}$ \\
\hline & Medium & $51.8 \mathrm{~cd}$ & $49.0 \mathrm{ef}$ & $50.4 \mathrm{de}$ & $52.5 \mathrm{bc}$ \\
\hline & Large & $47.6 \mathrm{fg}$ & $46.4 \mathrm{~g}$ & $45.9 \mathrm{~g}$ & $49.0 \mathrm{ef}$ \\
\hline \multirow{3}{*}{ Chroma } & Small & $41.2 \mathrm{ab}$ & $41.6 \mathrm{a}$ & $42.2 \mathrm{a}$ & $40.9 b$ \\
\hline & Medium & $40.0 \mathrm{bc}$ & $36.8 \mathrm{de}$ & $38.2 \mathrm{~cd}$ & $39.2 \mathrm{bc}$ \\
\hline & Large & $36.7 \mathrm{de}$ & $35.0 \mathrm{ef}$ & $34.0 \mathrm{f}$ & $36.7 \mathrm{de}$ \\
\hline \multirow{3}{*}{ Hue } & Small & $120 \mathrm{~b}$ & $117 \mathrm{~d}$ & $114 \mathrm{f}$ & $109 \mathrm{~g}$ \\
\hline & Medium & $120 \mathrm{~b}$ & $120 \mathrm{~b}$ & $118 \mathrm{c}$ & $116 \mathrm{e}$ \\
\hline & Large & $122 \mathrm{a}$ & $121 \mathrm{a}$ & $121 \mathrm{a}$ & $117 \mathrm{de}$ \\
\hline \multirow{3}{*}{$\begin{array}{l}\text { Carotenoids } \\
\left(\mathrm{mg} \mathrm{kg}^{-1}\right)\end{array}$} & Small & $4.41 \mathrm{~b}$ & $5.01 \mathrm{~b}$ & $8.05 \mathrm{a}$ & $7.75 \mathrm{a}$ \\
\hline & Medium & $2.77 \mathrm{~d}$ & $4.24 b c$ & $4.34 \mathrm{bc}$ & $4.40 \mathrm{bc}$ \\
\hline & Large & $2.92 \mathrm{~d}$ & $3.42 \mathrm{~cd}$ & $4.38 \mathrm{bc}$ & $4.26 \mathrm{bc}$ \\
\hline \multirow{3}{*}{$\begin{array}{l}\text { Chlorophyll a } \\
\left(\mathrm{mg} \mathrm{kg}^{-1}\right)\end{array}$} & Small & $72 \mathrm{~cd}$ & $102 \mathrm{abc}$ & $76 \mathrm{~cd}$ & $31 \mathrm{e}$ \\
\hline & Medium & $74 \mathrm{~cd}$ & $131 \mathrm{a}$ & $117 \mathrm{ab}$ & $35 \mathrm{e}$ \\
\hline & Large & $88 \mathrm{bc}$ & $118 \mathrm{ab}$ & $130 \mathrm{a}$ & $56 \mathrm{de}$ \\
\hline \multirow{3}{*}{$\begin{array}{l}\text { Chlorophyll b } \\
\left(\mathrm{mg} \mathrm{kg}^{-1}\right)\end{array}$} & Small & $36 \mathrm{cde}$ & $51 \mathrm{abc}$ & $39 \mathrm{cde}$ & $24 \mathrm{f}$ \\
\hline & Medium & $42 \mathrm{bcd}$ & $70 a$ & $64 \mathrm{ab}$ & $25 \mathrm{de}$ \\
\hline & Large & $49 a b c$ & $61 \mathrm{a}$ & $72 a$ & $43 \mathrm{bcd}$ \\
\hline
\end{tabular}

${ }^{(1)}$ Means followed by equal letters do not differ by Fisher's test, at $5 \%$ probability. ${ }^{(2)}$ Storage days plus 2 days at $20^{\circ} \mathrm{C}$.
(Figure $2 \mathrm{~A}$ and B). However, a contrasting behavior among maturity stages was observed during storage. In this work, continuous softening was observed in small fruit during storage, which was evidenced by both the reduction in firmness and the increase in DR. For this maturity stage, fruit DR showed a better correlation with sensory firmness evaluation than with a maximum force of compression tests (hardness) (Figure 2 B). A lack of good association between hardness and sensory texture has been also reported for other fruits showing nonmelting flesh, such as rabbiteye blueberry (Vaccinium ashei Reade) (Marshall et al., 2008). Medium and large-sized Zapallitos showed no variations for DR during 19 days, whereas firmness increased in this period. A similar trend has been verified for cucumber (Hurr et al., 2009) and may be likely due to peel formation. At long storage times, there was a reduction in firmness, in alignment with Massolo et al. (2013). Summer squash softening was correlated with pectin turnover and was delayed by cytokinin applications (Massolo et al., 2014). Medium and large fruit softened, but only at the last sampling date (Figure 2 A and B). Overall, the results from the present work suggest that textural losses are greater in small rather than in medium and large squashes, which could be related to water loss. The change in firmness

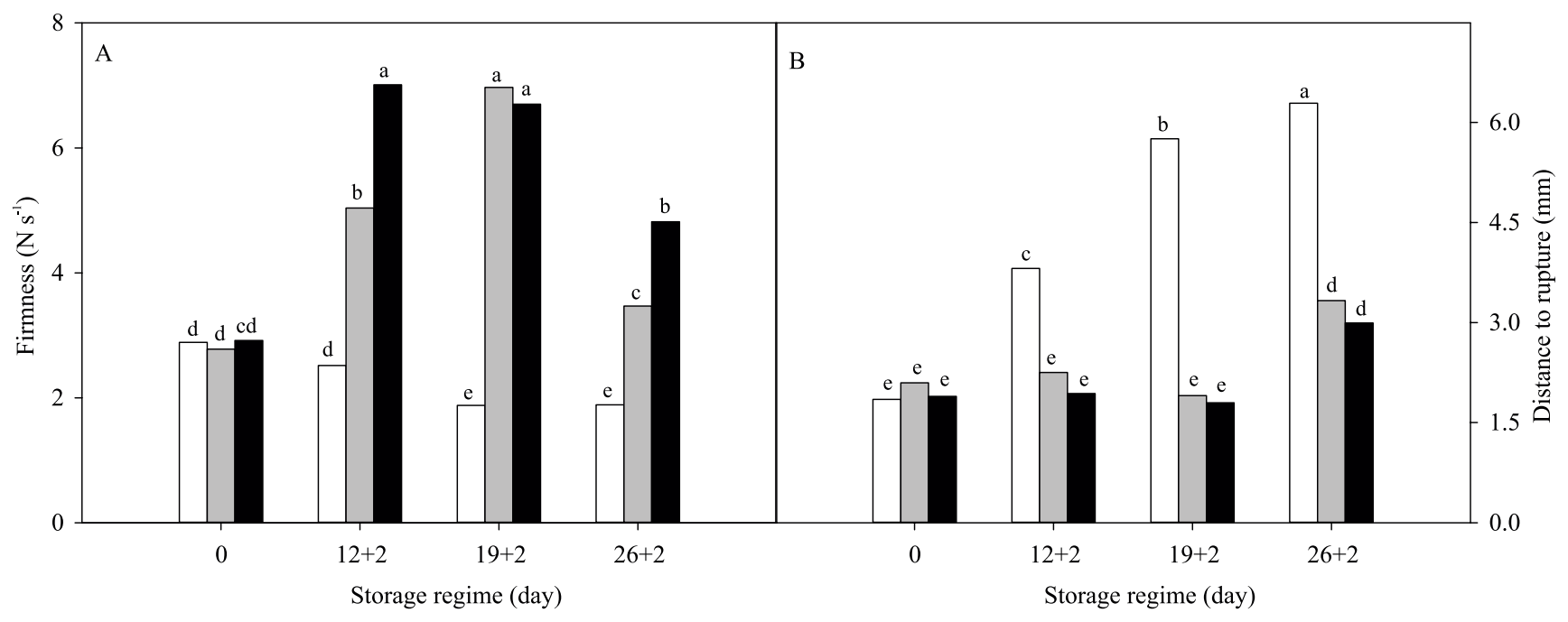

$\square$ Small $\square$ Medium $\square$ Large

Figure 2. Firmness (A) and distance to tissue rupture (B) of zapallito summer squash (Cucurbita maxima) stored for 0, 12,19 , or 26 days at $5^{\circ} \mathrm{C}$ and for 2 days at $20^{\circ} \mathrm{C}$. Different letters indicate significant differences by Fisher's test, at $5 \%$ probability. 
on medium and large fruit may be governed by both skin hardening and cell wall degradation (Lara et al., 2014); the latter is most important at the end of storage. Textural changes occurring in summer squash are largely dependent on maturity stage at harvest, as has been reported for other fruits (Brummell, 2006). In addition, as shown for nonmelting species, assessments of both firmness and tissue compression to rupture are needed to fully evaluate texture (Massolo et al., 2014), since both attributes vary on a maturity stagedependent manner.

Unlike most fruits, in which sugar content increases during development, reaching a maximum prior to overripe stages (Kader, 2002), no changes were found in zapallito summer squash (Figure 3 A). A slight reduction in sugar content was observed in all stages during storage. Acidity was markedly affected by both fruit maturity stage and storage time. In agreement with what occurs in most fruits (Etienne et al., 2013), acidity was higher in the least developed fruit (Figure 3 B). During storage, there was an increase in acidity in all stages, especially in small squash, with an acidity three-fold higher at the end of storage. Increased acidity may be also the result of the accumulation of Krebs cycle intermediates, especially in fruit in which low temperatures may affect normal metabolism to some extent. Higher acidity has been observed in temperate fruits stored for a long time, but that was attributed mainly to fermentative reactions (Tournas, 2005).

The total TEAC was greater in small fruit from harvest to the end of the storage period (Figure $4 \mathrm{~A}$ ). Antioxidant capacity remained almost unchanged in fruit of all developing stages even after 26 days, except in large fruit. At harvest, small fruit had the highest phenolic compound concentration of ca. $800 \mathrm{mg} \mathrm{kg}^{-1}$. The cold storage at $5^{\circ} \mathrm{C}$ plus two days at $20^{\circ} \mathrm{C}$ induced phenolic compound accumulation in small fruit and, to a lesser extent, in medium fruit (Figure 4 B). Previous work also found the induction of phenolic compound biosynthesis in zapallito stored at low temperature (Massolo et al., 2014). Overall, the profile of phenolic compound showed a similar trend to that found in $\mathrm{AOC}$, indicating that this is the main group of hydrophylic antioxidants in zapallito summer squashes. The decrease in phenolic compounds observed after 19+2 days in large fruit may be the result of phenolic polymerization and deposition required for rind formation (Stojanovic et al., 2017).

As expected, mass loss increased during storage time. After $26+2$ days, small fruit were fourfold

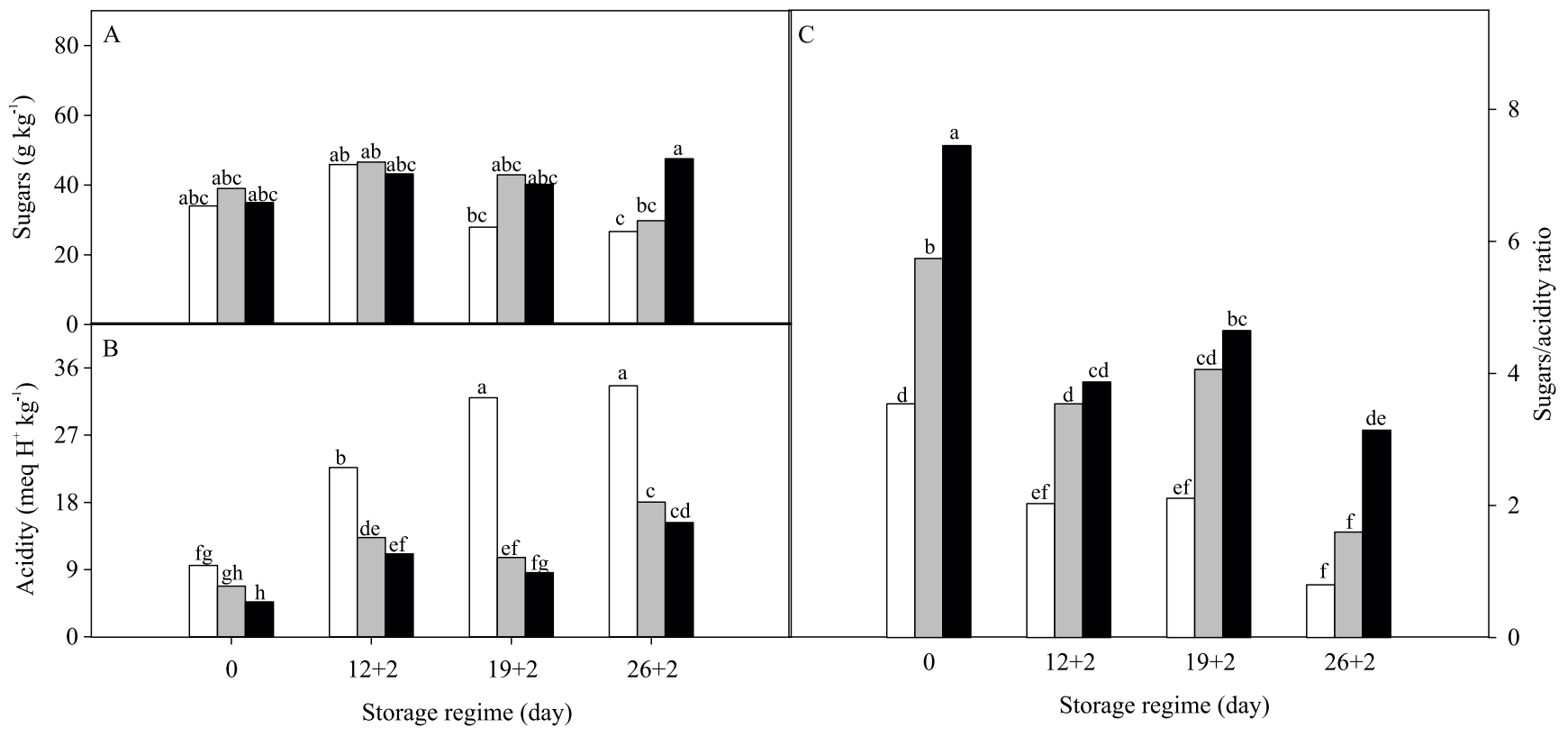

$\square$ Small $\square$ Medium $\square$ Large

Figure 3. Sugars (A), acidity (B), and sugars/acidity ratio (C) of zapallito summer squash (Cucurbita maxima) stored for $0,12,19$, or 26 days at $5^{\circ} \mathrm{C}$ and for 2 days at $20^{\circ} \mathrm{C}$. Different letters indicate significant differences by Fisher's test, at $5 \%$ probability. 
more susceptible to dehydration than large squashes (Figure $5 \mathrm{~A}$ ). This could be related to the highersurface to volume ratio in small fruit, though a lower cuticle formation and lack of rind skin hardening may have contributed as well. Similar results were found in eggplant by Zaro et al. (2014), who concluded that less developed fruit were more susceptible to deterioration during storage at $10^{\circ} \mathrm{C}$. Interestingly, medium and large fruit showed lower mass loss at $19+2$ and $26+2$ days than at $12+2$ days. At a first glance, this may seem contradictory, but could be explained by the fact that dehydration occurred mostly during the shelf-life period at $20^{\circ} \mathrm{C}$, due to the higher-vapor pressure deficit than at $5^{\circ} \mathrm{C}$. In this scenario, it could be envisioned that maintenance at low temperatures (when water loss was restricted) for longer periods may allow of further rind formation and wound healing, with a consequent decrease in fruit susceptibility to dehydration upon transfer to room temperatures.

The fruit deterioration index increased as storage time progressed (Figure 5 B). The initial symptoms

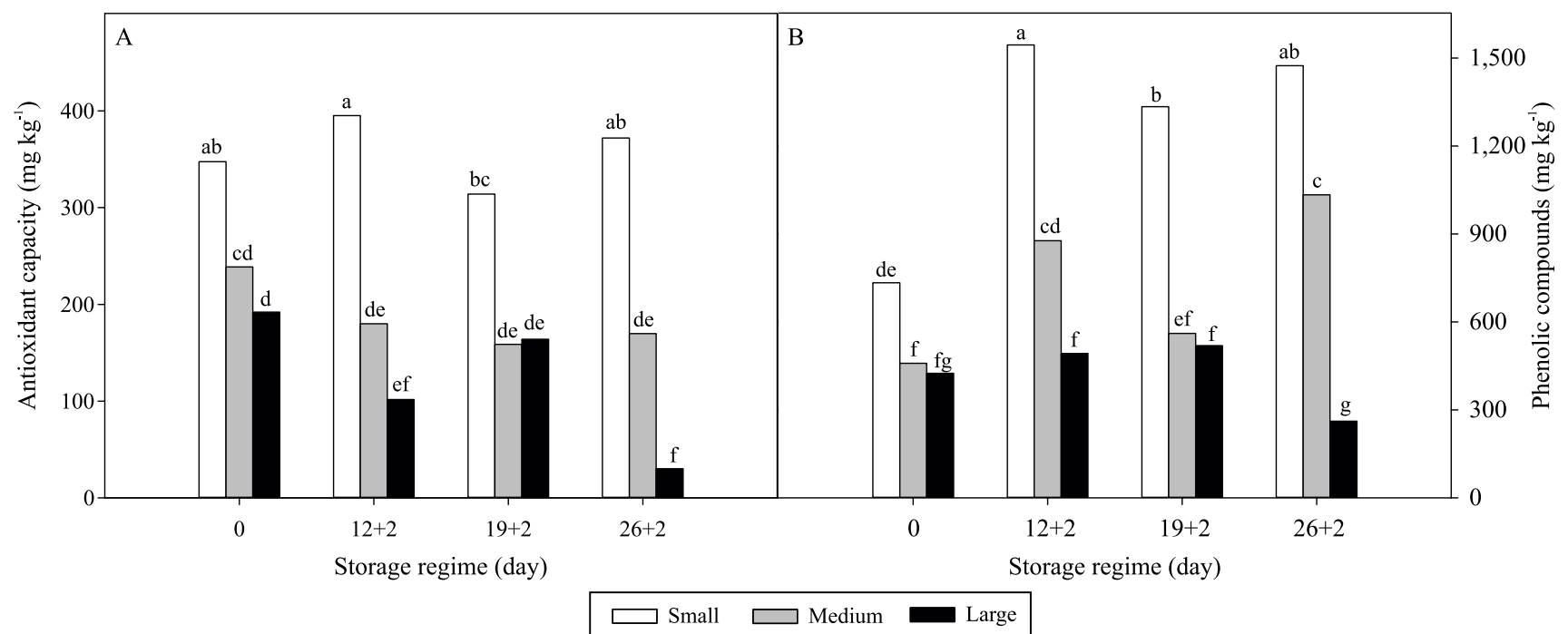

Figure 4. Antioxidant capacity (A) and phenolic compounds (B) of zapallito summer squash (Cucurbita maxima) stored for $0,12,19$, or 26 days at $5^{\circ} \mathrm{C}$ and for 2 days at $20^{\circ} \mathrm{C}$. Different letters indicate significant differences by Fisher's test, at $5 \%$ probability.

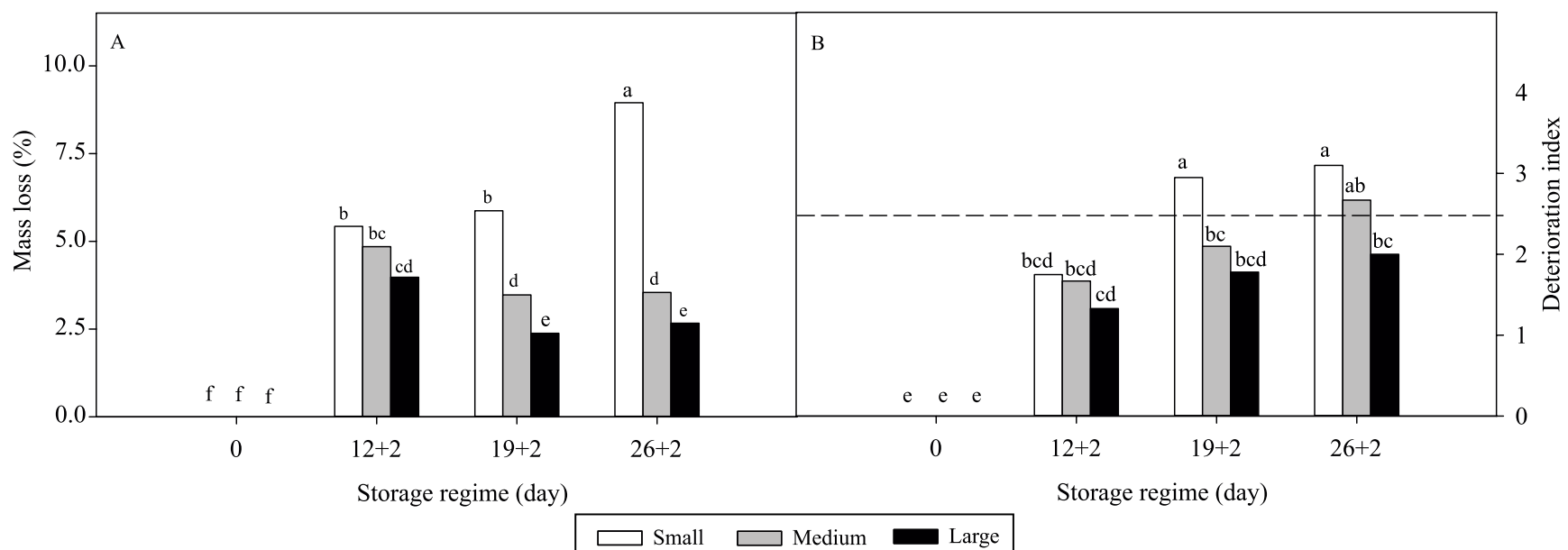

Figure 5. Mass loss (A) and deterioration index (B) of zapallito summer squash (Cucurbita maxima) stored for 0, 12, 19, or 26 days at $5^{\circ} \mathrm{C}$ and for 2 days at $20^{\circ} \mathrm{C}$. Different letters indicate significant differences by Fisher's test, at $5 \%$ probability. The dotted line represents the limit of product commercialization (deterioration index $\leq 2.5$ ). 
contributing to fruit quality loss were surface dehydration and yellowing, especially in "baby" squashes. At longer times, a clear reduction in firmness was detected. These results were in agreement with what was observed in other immature fruits in different stages of development and stored under refrigeration (Zaro et al., 2014). Fungal decay was manifested at the last sampling date in medium and large fruit, as opposed to 19 days in small fruit. After $12+2$ days, no differences were found for the deterioration index among maturity stages. However, subsequently, significantly higher values for this index were found in less mature fruit. Considering a deterioration index value of 2.5, which was set as a limit for fruit marketing, a shelf life of 12,19 , and 26 days at $5^{\circ} \mathrm{C}$ plus 2 days at $20^{\circ} \mathrm{C}$ could be expected for small, medium, and large fruit. The initial chilling injury symptom was a loss of glossiness, followed by the formation of subtle surface depressions, which subsequently became coalescent and formed necrotic scalds at terminal stages in which fungal attack occurred. Studies in zucchini summer squashes showed that the fruit are highly susceptible to chilling injury and that storage below $5^{\circ} \mathrm{C}$ for 2 days is sufficient to detect surface damages (Molinar et al., 1999). Results from the present study suggest that zapallito squashes would be less sensitive to this type of injury, since its initial symptoms appeared after 12 days at $0^{\circ} \mathrm{C}$ and 2 days at $20^{\circ} \mathrm{C}$ (Figure 6). Symptomatology of chilling injury at $0^{\circ} \mathrm{C}$ was similar in the three developmental stages. However, the least developed fruit showed higher incidence and severity of this injury than more mature fruit (Figure $6 \mathrm{~A}$ and B). This is in line with what has been reported for most vegetable fruit (Wang, 2009), but not for eggplants (Zaro et at., 2014). No significant differences were detected by visual inspection for chilling injury susceptibility between medium and large zapallito. However, in contrast to the previously described for fruit stored at nonchilling temperatures, medium fruit showed higher dehydration than large fruit, suggesting that there may be some differences for cold damage also between these two maturity stages (Figure $6 \mathrm{C}$ ).

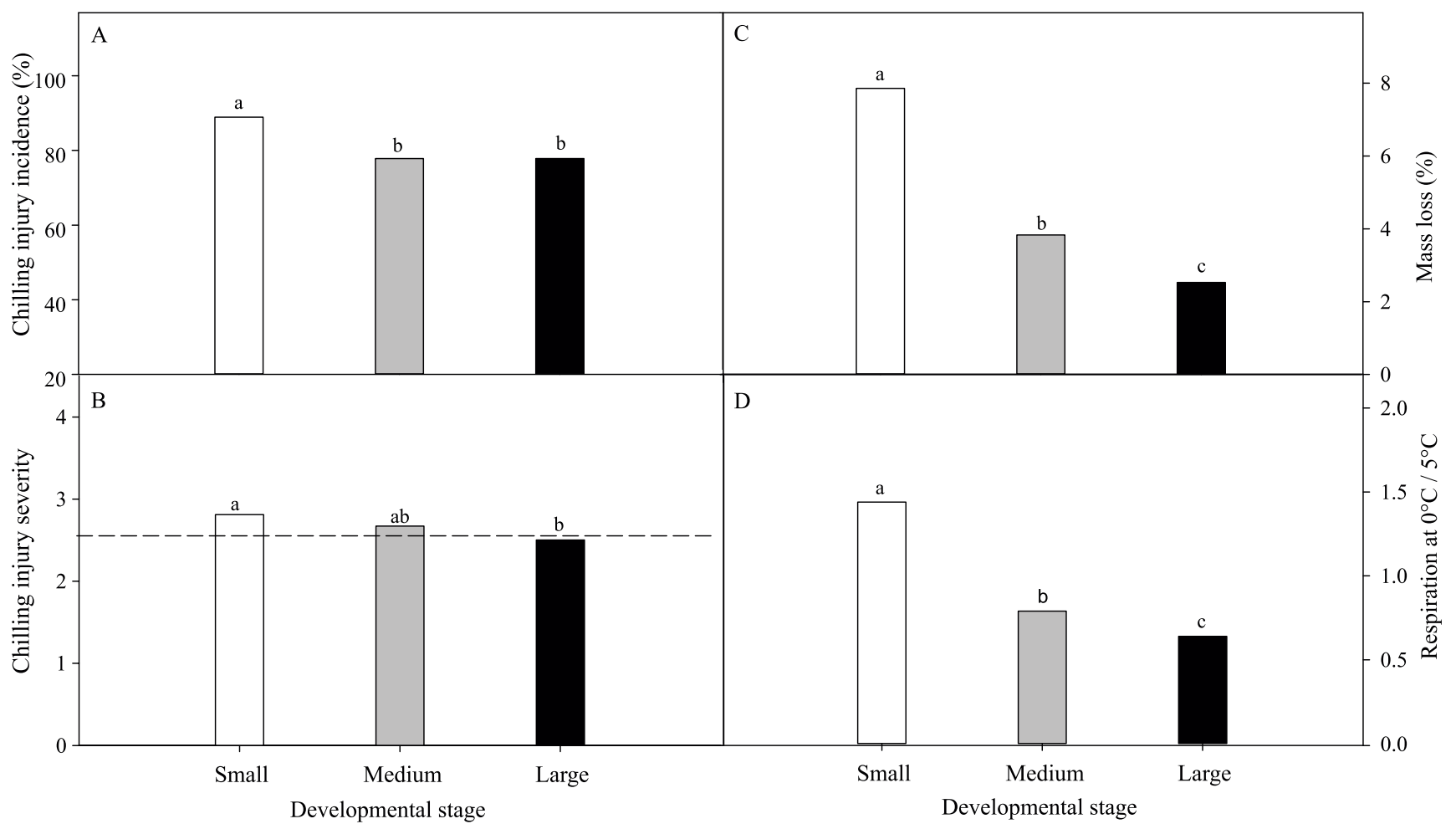

Figure 6. Chilling injury incidence (A) and severity (B) and mass loss (C) of zapallito summer squash (Cucurbita maxima) stored for 12 days at $0^{\circ} \mathrm{C}$ and for 2 days at $20^{\circ} \mathrm{C}$, as well as respiration increase (D) when stored for 12 days at 0 or $5^{\circ} \mathrm{C}$ and for 2 days at $20^{\circ} \mathrm{C}$. Different letters indicate significant differences by Fisher's test, at $5 \%$ probability. The dotted line represents the limit of product commercialization (deterioration index $\leq 2.5$ ). 
As expected, the highest increase of c.a. $300 \%$ in respiration in fruit stored at $0^{\circ} \mathrm{C}$ occurred in the highly sensitive "baby" squashes (Figure 6 D). In this case, significant differences were found between medium and large fruit, which were the first ones to show a greater respiratory increase, indicating a progressive decrease in chilling injury sensitivity accompanying maturation.

\section{Conclusions}

1. The maturation of zapallito squash (Cucurbita maxima) occurs with no major changes in firmness and sugars; however, ripening progression decreases respiration rate and acidity.

2. Small zapallitos have a greater antioxidant capacity, but a shorter postharvest life, which is limited by their high susceptibility to dehydration, softening, decay, and chilling injury, compared with medium and large fruit.

3. Summer squash quality and storage capacity are greatly affected by the maturity stage at harvest.

\section{Acknowledgments}

To Consejo Nacional de Investigaciones Científicas y Técnicas (Conicet, PIP-0098) and to Agencia Nacional de Promoción Científica y Tecnológica (PICT 20163690), for financial support.

\section{References}

AHMAD, M.S.; SIDDIQUI, M.W. Postharvest quality assurance of fruits: practical approaches for developing countries. New York: Springer, 2015. 265p. DOI: https://doi.org/10.1007/978-3319-21197-8.

ARNAO, M.B.; CANO, A.; ACOSTA, M. The hydrophilic and lipophilic contribution to total antioxidant activity. Food Chemistry, v.73, p.239-244, 2001. DOI: https://doi.org/10.1016/ S0308-8146(00)00324-1.

BOONSIRI, K.; KETSA, S.; DOORN, W.G. van. Seed browning of hot peppers during low temperature storage. Postharvest Biology and Technology, v.45, p.358-365, 2007. DOI: https://doi.org/10.1016/j.postharvbio.2007.03.014.

BRUMMEL, D.A. Cell wall disassembly in ripening fruit. Functional Plant Biology, v.33, p.103-119, 2006. DOI: https://doi.org/10.1071/FP05234.

CANTWELL, M.; KASMIRE, R.F. Postharvest handling systems: fruit vegetables. In: KADER, A.A. (Ed.). Postharvest technology of horticultural crops. $3^{\text {rd }}$ ed. Oakland: University of California, Agriculture and Natural Resources, 2002. p.407-421.
CONTACTO RURAL: INTRODUCCIÓN A LAS CIENCIAS AGRARIAS Y FORESTALES. 2012. Available at: <https:// www.agro.unlp.edu.ar/sites/default/files/paginas/contacto rural_3_2012.pdf>. Accessed on: Sept. 32018.

COSTA, L.; VICENTE, A.R.; CIVELLO, P.M.; CHAVES, A.R.; MARTÍNEZ, G.A. UV-C treatment delays postharvest senescence in broccoli florets. Postharvest Biology and Technology, v.39, p.204-210, 2006. DOI: https://doi.org/10.1016/j. postharvbio.2005.10.012.

COTE, S.; RODONI, L.; MICELI, E.; CONCELLÓN, A.; CIVELlO, P.M.; VICENTE, A.R. Effect of radiation intensity on the outcome of postharvest UV-C treatments. Postharvest Biology and Technology, v.83, p.83-89, 2013. DOI: https://doi.org/10.1016/j.postharvbio.2013.03.009.

ETIENNE, A.; GÉNARD, M.; LOBIT, P.; MBEGUIÉ-AMBÉGUIÉ, D.; BUGAUD, C. What controls fleshy fruit acidity? A review of malate and citrate accumulation in fruit cells. Journal of Experimental Botany, v.64, p.1451-1469, 2013. DOI: https://doi.org/10.1093/jxb/ert035.

HASPERUÉ, J.H.; GUARDIANELLI, L.; RODONI, L.M.; CHAVES, A.R.; MARTÍNEZ, G.A. Continuous white-blue LED light exposition delays postharvest senescence of broccoli. LWT - Food Science and Technology, v.65, p.495-502, 2016. DOI: https://doi.org/10.1016/j.lwt.2015.08.041.

HURR, B.M.; HUBER, D.J.; VALLEJOS, C.E.; TALCOTT, S.T. Developmentally dependent responses of detached cucumber (Cucumis sativus L.) fruit to exogenous ethylene. Postharvest Biology and Technology, v.52, p.207-215, 2009. DOI: https://doi.org/10.1016/j.postharvbio.2008.12.006.

IGNAT, T.; SCHMILOVITCH, Z.; FEFOLDI, J.; BERNSTEIN, N.; STEINER, B.; EGOZI, H.; HOFFMAN, A. Nonlinear methods for estimation of maturity stage, total chlorophyll, and carotenoid content in intact bell peppers. Biosystems Engineering, v.114, p.414-425, 2013. DOI: https://doi.org/10.1016/j.biosystemseng.2012.10.001.

KADER, A.A. (Ed.). Postharvest technology of horticultural crops. $3^{\text {rd }}$ ed. California: University of California, Agriculture and Natural Resources, 2002. 535p.

KAISER, C.; ERNST, M. Baby vegetables. 2013. Available at: $<$ https://www.uky.edu/Ag/CCD/introsheets/babyveggies.pdf $>$. Accessed on: Aug. 242017.

LANGER, S.E.; OVIEDO, N.C.; MARINA, M.; BURGOS, J.L.; MARTÍNEZ, G.A.; CIVELLO, P.M.; VILLARREAL, N.M. Effects of heat treatment on enzyme activity and expression of key genes controlling cell wall remodeling in strawberry fruit. Plant Physiology and Biochemistry, v.130, p.334-344, 2018. DOI: https://doi.org/10.1016/j.plaphy.2018.07.015.

LARA, I.; BELGE, B.; GOULAO, L.F. The fruit cuticle as a modulator of postharvest quality. Postharvest Biology and Technology, v.87, p.103-112, 2014. DOI: https://doi.org/10.1016/j. postharvbio.2013.08.012.

LEMOINE, M.L.; CIVELlO, P.M.; CHAVES, A.R.; MARTÍNEZ, G.A. Influence of a combined hot air and UV-C treatment on quality parameters of fresh-cut broccoli florets at $0^{\circ} \mathrm{C}$. International Journal of Food Science and Technology, 
v.45, p.1212-1218, 2010. DOI: https://doi.org/10.1111/j.13652621.2010.02269.x.

MARSHALL, D.A.; SPIERS, J.M.; STRINGER, S.J. Blueberry splitting tendencies as predicted by fruit firmness. HortScience, v.43, p.567-570, 2008. DOI: https://doi.org/10.21273/ HORTSCI.43.2.567.

MASSOLO, J.F.; CONCELLÓN, A.; CHAVES, A.R.; VICENTE, A.R. Use of 1-methylcyclopropene to complement refrigeration and ameliorate chilling injury symptoms in summer squash. CyTA - Journal of Food, v.11, p.19-26, 2013. DOI: https://doi.org/10.1080/19476337.2012.676069.

MASSOLO, J.F.; LEMOINE, M.L.; CHAVES, A.R.; CONCELLÓN, A.; VICENTE, A.R. Benzyl-aminopurine (BAP) treatments delay cell wall degradation and softening, improving quality maintenance of refrigerated summer squash. Postharvest Biology and Technology, v.93, p.122-129, 2014. DOI: https://doi.org/10.1016/j.postharvbio.2014.02.010.

MOLINAR, R.; AGUIAR, J.; GASKELL, M.; MAYBERRY, K. Summer squash production in California. 1999. Available at: $<$ http://anrcatalog.ucdavis.edu/pdf/7245.pdf $>$. Accessed on: Nov. 262016.

OBRERO, A.; GONZÁLEZ-VERDEJO, C.I.; DIE, J.V.; GÓMEZ, P.; DEL RÍO-CELESTINO, M.; ROMÁN, B. Carotenogenic gene expression and carotenoid accumulation in three varieties of Cucurbita pepo during fruit development. Journal of Agricultural and Food Chemistry, v.61, p.6393-6403, 2013. DOI: https://doi.org/10.1021/jf4004576.

RAFFO, M.D.; PONCE, N.M.A.; SOZZI, G.O.; VICENTE, A.R.; STORTZ, C.A. Compositional changes in 'Bartlett' pear (Pyrus communis L.) cell wall polysaccharides as affected by sunlight conditions. Journal of Agricultural and Food Chemistry, v.59, p.12155-12162, 2011. DOI: https://doi.org/10.1021/jf203950d.
RAJASREE, R.S.; SIBI, P.I.; FEMI, F.; WILLIAM, H. Phytochemicals of Cucurbitaceae family-a review. International Journal of Pharmacognosy and Phytochemical Research, v.8, p.113-123, 2016.

STOJANOVIĆ, B.T.; MITIĆ, S.S.; STOJANOVIĆ, G.S.; MITIĆ, M.N.; KOSTIĆ, D.A.; PAUNOVIĆ, D.D.; ARSIĆ, B.B.; PAVLOVIĆ, A.N. Phenolic profiles and metal ions analyses of pulp and peel of fruits and seeds of quince (Cydonia oblonga Mill.). Food Chemistry, v.232, p.466-475, 2017. DOI: https://doi.org/10.1016/j.foodchem.2017.04.041.

SUSLOW, T.V.; CANTWELL, M. Squash (soft rind): recommendations for maintaining postharvest quality. 2014. Available at: <http://postharvest.ucdavis.edu/ Commodity_Resources/Fact_Sheets/Datastores/Vegetables English/?uid=33\&ds=799>. Accessed on: Aug. 242017.

TOURNAS, V.H. Spoilage of vegetable crops by bacteria and fungi and related health hazards. Critical Reviews in Microbiology, v.31, p.33-44, 2005. DOI: https://doi.org/10.1080/10408410590886024.

VILLARREAL, N.M; BUSTAMANTE, C.A.; CIVELLO, P.M.; MARTÍNEZ, G.A. Effect of ethylene and 1-MCP treatments on strawberry fruit ripening. Journal of the Science of Food and Agriculture, v.90, p.683-689, 2010. DOI: https://doi.org/10.1002/ jsfa.3868.

WANG, C.Y. Chilling injury of fruits and vegetables. Food Reviews International, v.5, p.209-236, 2009. DOI: https://doi.org/10.1080/87559128909540850.

ZARO, M.J.; KEUNCHKARIAN, S.; CHAVES, A.R.; VICENTE, A.R.; CONCELLÓN, A. Changes in bioactive compounds and response to postharvest storage conditions in purple eggplants as affected by fruit developmental stage. Postharvest Biology and Technology, v.96, p.110-117, 2014. DOI: https://doi.org/10.1016/j. postharvbio.2014.05.012. 